\title{
Effects of Recent and Potential Land Use and Climate Changes on Runoff and Sediment Load in the Upper Yellow River Basin, China
}

\author{
Zhenyu Lv ${ }^{1,2}$, Tianling Qin ${ }^{1 *}$, Yu Wang ${ }^{3}$, Jianxin Mu${ }^{1}$, Shanshan Liu ${ }^{1}$, Hanjiang Nie ${ }^{1,2}$ \\ ${ }^{1}$ State Key Laboratory of Simulation and Regulation of Water Cycle in River Basin, China Institute of Water Resources \\ and Hydropower Research, Beijing, 100038, China \\ ${ }^{2}$ Department of Hydraulic Engineering, Tsinghua University, Beijing 100084, China \\ ${ }^{3}$ Yellow River Engineering Consulting Co., Ltd., Zhengzhou, China
}

Received: 19 December 2019

Accepted: 23 March 2020

\begin{abstract}
Changes in water and sediment conditions in the Upper Yellow River Basin (UYRB), which contains the ecological barrier and "water tower" of the entire Yellow River Basin, directly affect the development of the downstream ecological environment. In this study, the impacts of recent and potential land use and climate changes on runoff and sediment load were investigated through statistical analysis, land-use maps, scenario estimations, and hydrological modelling. The temporal trends and abrupt changes in hydro-meteorological elements from 1957-2010 were analysed using linear regressions and moving-t tests. Transformations in land use from 1990 to 2014 were determined using a transfer matrix analysis. The back propagation neural network was constructed to modify and integrate several general climate models, and it projected the climate change evolution characteristics in the UYRB from 2021 to 2100 under different emission scenarios. On this basis, the effects of recent and potential land use and climate changes on runoff and sediment load were quantified using the Soil and Water Assessment Tool (SWAT) hydrological model and fifteen climate scenarios, respectively. The results show a significant decreasing trends for both runoff and sediment loads with warmer and wetter climate conditions in the past 50 years. An abrupt change in runoff occurred in 1990, and a notable change in sediment load occurred in 2000 which was defined as the dividing year of the study period. The warm and wet climate characteristics of the UYRB will continue from 2021 to 2100 . Over the past 20 years, the transformation of land use in the URYB has intensified. Therefore, land use changes between 1990 and 2000 show significant increasing wetland trends and decreasing bare land and grassland trends. The SWAT simulation results indicated that climate changes have had a more significant impact on runoff than land use changes in the past 20 years, increasing runoff by $6.32 \%$. Both land use and climate changes have great impacts on sediment load reduction. For the next 80 years, the potential land use change demonstrated greater impacts on runoff and sediment load than climate changes. The runoff
\end{abstract}

*e-mail: tianling406@126.com 
and sediment load exhibited different trends under various climate conditions and emission scenarios. The results obtained in this study can provide useful information for water resource management, soil and water conservation, and ecological protection in the UYRB.

Keywords: land use and climate scenarios, runoff, sediment load, soil and water assessment tool, upper Yellow River Basin

\section{Introduction}

Global climate changes accelerate water circulation speeds and alter hydrothermal features, leading to an increase in extreme event frequency and influencing upstream water inflows, sediment inflows, and river runoff and sediment transport abilities [1-3]. Changes in underlying surface conditions alter the capacity of land cover to regulate water and immobilise soil, affecting water and sediment fluxes [4-7]. Under the combined effects of land use and climate changes, most river runoff and sediment processes have altered globally [8-10].

The Yellow River, or the "Mother River", is an important ecological barrier and economic zone in China. In recent years, climate change and human activities, such as soil and water conservation measures have altered the runoff and sediment processes of the Yellow River Basin [11, 12]. In the past 100 years, runoff fluctuations have changed in ladder type [13]. After 1960, runoff gradually decreased, and the Yellow River dried up multiple times [14]. Influenced by runoff and changes in underlying surface conditions, the flood carrying capacity and sediment transportation of the Yellow River have been weakened. For nearly 60 years, both the river sediment and sediment discharge into sea drastically decreased [15]. The Upper Yellow River Basin (UYRB) (Fig. 1) is the ecological barrier and the "water tower" of the entire Yellow River Basin, where changes in water and sediment conditions directly affect the development of in the downstream environment [16]. An intricate underlying surface structure and fragile ecological environment make the UYRB more sensitive to climate change [17]. The UYRB includes two economic centres, Xining and Lanzhou, and it is significantly affected by human activities [18]. There is an urgent need to quantify the impacts of recent land use and climate changes on runoff and sediment loads in the UYRB and to predict the evolution characteristics of runoff and sediment load under future land use and climate conditions. These analyses can provide support for water resource management and environmental protection in the Yellow River Basin.

Because of the complexity of runoff and sediment process changes, scholars have explored the effects of land use and climate change on runoff and sediment process with different temporal and spatial scales [19-22]. Research methods have included paired catchment [23], multivariate statistical analysis [19], and hydrological models [24]. The paired catchment method requires conducting long-term hydrometry on two similar drainage basins to study the effects of environmental changes on the hydrological process, which is both time-consuming and limiting [25]. Multivariate statistical analyses quantify the effects of land use and climate changes on the hydrological process; however, there is a lack of descriptions of physical processes and solutions to the elemental multicollinearity problem [26]. In recent years, the hydrological model simulation method, because of its elaborate descriptions of large-scale physical processes, has been widely applied in research on the effects of land use and climate changes on the hydrological process [27-31]. The coupling of distributed hydrological models and global climate patterns can not only explain the physical mechanisms of runoff and sediment process changes but also predict the responses to future land use and climate changes [32-34].

Presently, the mechanisms runoff and sediment process changes in the UYRB are unclear. There is an urgent need to explore the effects of recent and potential land use and climate changes on runoff and sediment loads. In this study, the UYRB, situated above Jingyuan County, was utilised as the study area to conduct the simulation research. The objectives of this study were to: (1) detect the temporal trends and abrupt changes in hydro-meteorological elements in the UYRB over the past 50 years based on measured data from 1957 to 2010; (2) explore the transformation of land use over the past 20 years according to 1990, 2000, 2005, and 2014 land-use maps; (3) modify and integrate global climate models to predict the evolution of climate changes in the next 80 years; and (4) quantify the impacts of recent and potential land use and climate changes on runoff and sediment load using the Soil and Water Assessment Tool (SWAT) model and scenario analysis technique.

\section{Material and Methods}

Study Area

Data Description

Temporal Trend Analysis and Change Point Detection

Estimations of Future Climate Changes

Distributed Hydrological Model 


\section{Construction of Land Use and Climate Changes Scenarios}

The UYRB, situated above Jingyuan County, is the study area of this research. It lies in the latitude range of $32.0-39.0^{\circ} \mathrm{N}$ and longitude range of $96.0-106.0^{\circ} \mathrm{E}$, and it has an area of 0.253 million $\mathrm{km}^{2}$, accounting for $33.56 \%$ of the total area of the Yellow River Basin (Fig. 1). The elevation ranges from $1237 \mathrm{~m}$ to $6253 \mathrm{~m}$, with an overall fall of $5016 \mathrm{~m}$ from the southwest to northwest. The research area includes three provinces, Qinghai, Gansu, and Sichuan, and two economic centres with a combined population of 6.5 million inhabitants, Xining and Lanzhou.

The UYRB is located in a mid-latitude region with a typical continental climate. The average annual precipitation is approximately $500 \mathrm{~mm}$, which is concentrated in the summer. The average annual temperature ranges from $-4.7^{\circ} \mathrm{C}$ to $12^{\circ} \mathrm{C}$. Influenced by the subtropical westerly jet, El Niño, East Asian monsoons, etc., meteorological factors in the research area vary remarkably.

Vegetation in the UYRB is dominated by Alpine meadows and steppes and also includes evergreen broad-leaved forests, shrubs, swamps, and sparse alpine vegetation. There are 20 vegetation sub-categories in total.

The data sets used in this study include meteorological data such as precipitation and temperature data; hydrological data such as runoff and sediment load data; spatial data such as digital elevation model (DEM), land-use map, and soil type data; and future climate data obtained from 20 general climate models (GCMs) in the Fourth Assessment Report of the Intergovernmental Panel on Climate Change (IPCC) (Table 1). The long-term annual hydrological and meteorological data from 1957 to 2010 were used for a trend analysis and to detect abrupt changes. Landuse maps from 1990, 2000, 2005, and 2010 were used to analyse the evolution of land use changes across the UYRB over the past 20 years and to design future potential land use change scenarios. Daily hydrometeorological data from 1991 to 2010, a land-use map from 1990, and other spatial data were employed for the SWAT model. Daily GCMs precipitation and temperature data for 2021-2100 and the designed land use change scenarios were adopted as the input scenarios of the SWAT model to evaluate the effects of potential land use and climate changes on runoff and sediment loads.

The temporal trends of hydro-meteorological factors were analysed using the linear regression method. The moving-t test was used in this study to identify change points. The test can accurately locate the most significant time points of abrupt changes by comparing the statistical parameter $t$ and the standard value $t_{\alpha}$ [35]. The formula for the parameter $t$ is as follows:

$$
t=\frac{\overline{x_{1}}-\overline{x_{2}}}{s \sqrt{\frac{1}{n_{1}}+\frac{1}{n_{2}}}}
$$

and

$$
s=\sqrt{\frac{n_{1} s_{1}^{2}+n_{2} s_{2}^{2}}{n_{1}+n_{2}-2}}
$$

...where $\bar{x}_{\mathrm{i}}, s_{\mathrm{i}}$, and $n_{\mathrm{i}}$ are the mean, standard deviation, and size, respectively, of the two independent samples $(i=1,2)$. The degrees of freedom in the moving t-test are $n_{1}+n_{2}-2$.

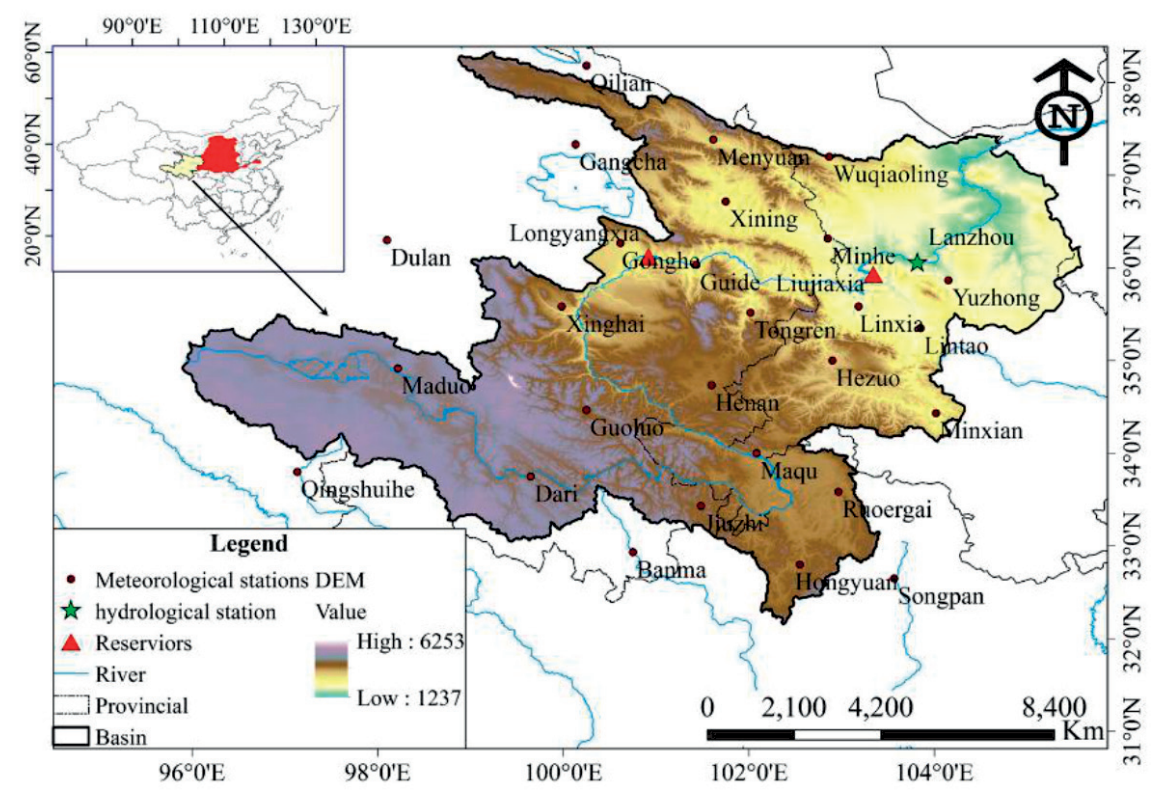

Fig. 1. Study area and hydro-meteorological stations. 
Table 1. Data types, sources, and descriptions.

\begin{tabular}{|c|c|c|}
\hline Data types & Source & Description \\
\hline Meteorological data & China Meteorological Administration & Daily data of 34 stations from 1957 to 2010 \\
\hline Hydrological data & Yellow River Conservancy Commission & Monthly data in Lanzhou station from 1957 to 2010 \\
\hline $\begin{array}{c}\text { Digital Elevation Model } \\
\text { (DEM) }\end{array}$ & National Genomatics Centre of China & Resolution 90×90 m \\
\hline Land-use map & $\begin{array}{c}\text { Resource and Environment Data Cloud } \\
\text { Platform of Chinese Academy of Sciences }\end{array}$ & $\begin{array}{c}1990,2000,2005 \text { and 2014 with an resolution of } \\
90 \times 90 \mathrm{~m}\end{array}$ \\
\hline Soil type-map & China Soil Data Survey, China soil Database & Reclassification according to soil category in China \\
\hline $\begin{array}{c}\text { Future Precipitation and } \\
\text { Temperature data }\end{array}$ & $\begin{array}{c}\text { 20GCMs in the Fourth assessment Report } \\
\text { (AR4) of the Intergovernmental Panel On } \\
\text { Climate Change (IPCC) }\end{array}$ & Daily data from 1900 to 2100 \\
\hline
\end{tabular}

The size of the statistic parameter $t$ varies based on the length of the two sub-samples. Instead of dividing the data into two sub-samples as a potential jump point, we applied the t-test to a subseries with a fixed length of $10 \mathrm{a}$; therefore, the length of the moving window is 20 a. Two significance levels, $\alpha=0.05$ and $\alpha=0.1$, were used. When $\alpha=0.05, t_{\alpha}=2.1$, and when $\alpha=0.1$, $t_{\alpha}=1.73$. If $|t| \geq t_{\alpha}$, then the point is considered a jump point at significance level $\alpha$, and the point with the largest $|t|$ is the most probable change point. Therefore, the time series was divided into two parts at the location of the change point.

The simulated effects of future climate changes differ between GCMs, and the average effect from many models has been proven to be superiour to than that from one model. Hence, we selected data sets from six models including GFDL_CM2_0, GFDL_CM2_1, INMCM3_0, IPSL_CM4, MIROC3_2_M, and NCAR PCM1 (Table 2). These models conducted simulations under the $\mathrm{A} 1 \mathrm{~B}, \mathrm{~A} 2$, and $\mathrm{B} 1$ emission scenarios of the IPCC, which span nearly the entire IPCC scenario range [36]. The data sets from the GCMs were interpolated into a common $1^{\circ} \times 1^{\circ}$ grid through space interpolation and were then gathered and corrected using a back propagation (BP) network.

The BP network was trained using the BP toolkit in MATLAB with monthly precipitation and temperature data sets from the GCMs during 1957-2000 as the inputs and the corresponding measured UYRB values as the training targets. With 2001-2010 as the validation period, the simulation precision of the BP network was evaluated (Fig. 2 and Table 3). The annual and interannual precipitation and temperature changes in the research area for the next 80 years $(2021-2100)$ was predicted by the trained BP network.

The SWAT hydrological model has been used to quantify the impacts of land use and climate changes on runoff and sediment loads under different scenarios. The SWAT model divides the entire watershed into sub-basins with essentially the same climatic conditions and then further subdivides the sub-basins into different hydrological response units (HRUs) according to land use patterns and soil types. Runoff and sediment simulations were conducted for each HRU independently and the results for the entire basin are aggregated through basin runoff concentration. This model has been widely applied in relevant fields such as hydrological simulation and forecasting [26, 37].

According to the temporal trend results and abrupt change points of annual runoff and sediment load in the study area, which are based on the 1990 land-use map data, the period 1991-2000 (before the change point) was considered to be the baseline condition for SWAT model calibration. Hence, 1991 to 1993 served as a warm-up period. The period from 2001 to 2010 (after the change point) was used for validation. The monthly observed runoff and sediment loads during 1991-2010 at the Lanzhou station were used to verify the model performance.

Table 2. Information on the six IPCC global coupled climate models used.

\begin{tabular}{|c|c|c|c|}
\hline Model & Country & Resolution $(\approx$ degree $)$ & Origination froup (s) \\
\hline GFDL_CM2_0 & USA & $2.5 \times 2.0$ & Geophysical Fluid Dynamics Laboratory \\
\hline GFDL_CM2_1 & USA & $2.5 \times 2.0$ & Geophysical Fluid Dynamics Laboratory \\
\hline INMCM3_0 & Russia & $5.0 \times 4.0$ & Institute of Numerical Mathematics, Russia \\
\hline IPSL_CM4 & France & $3.8 \times 2.5$ & Institute Pierre-Simon Laplace, France \\
\hline MIROC3_2_M & Japan & $2.8 \times 2.8$ & Center for Climate System Research \\
\hline NCAR_PCM1 & USA & $128 \times 64$ & National Center for Atmospheric Research \\
\hline
\end{tabular}




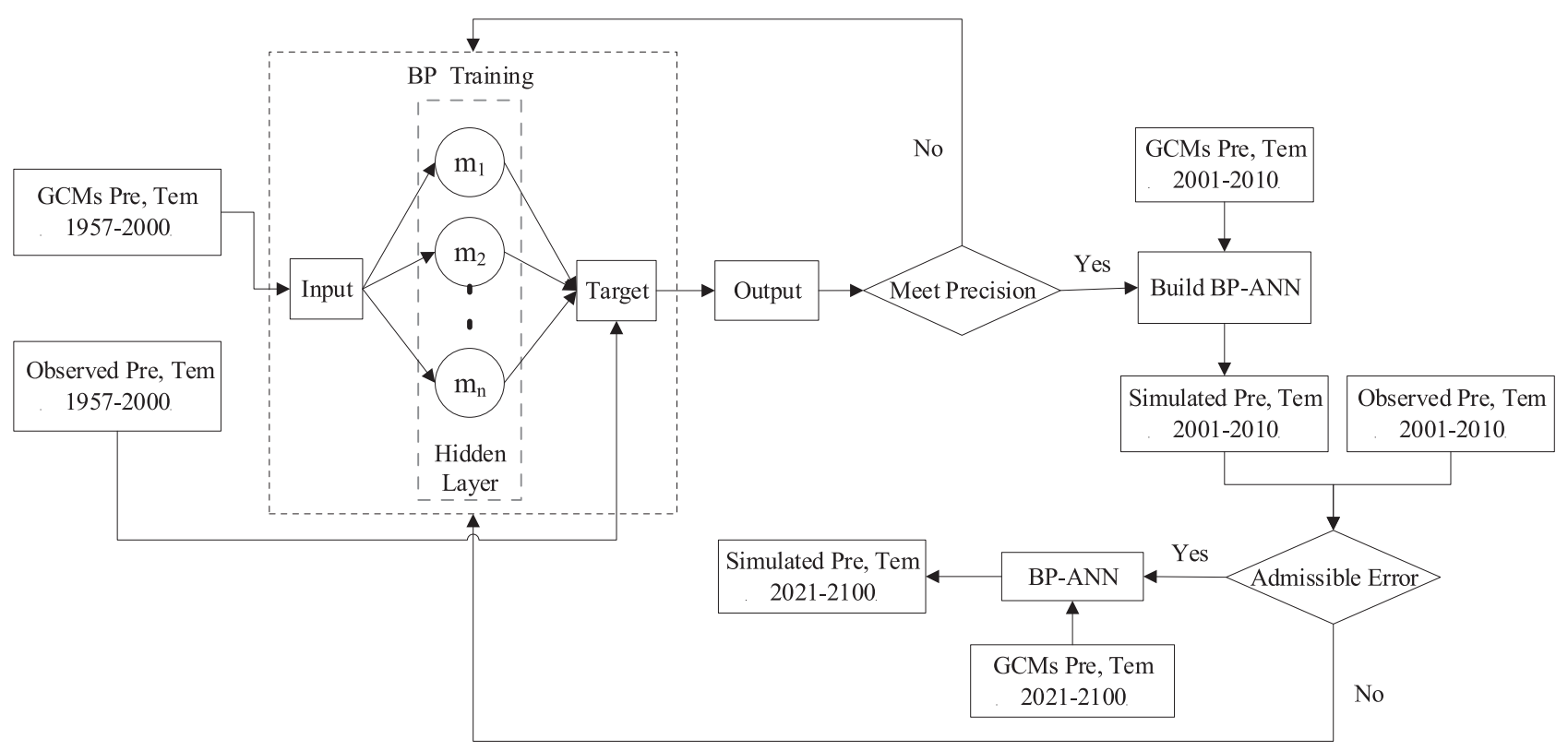

Fig. 2. The BP neural network establishment process. Pre: precipitation, Tem: temperature.

To quantify the impacts of the recent land use and climate changes on runoff and sediment load, two periods were selected based on the results of the trend analysis and change-point test of annual runoff and sediment load. The first period was from 1991 to 2000, before the change point, and the other was from 2001 to 2010, after the change point. The land-use maps of 1990 and 2000 served as the land use patterns of the two periods. Four design scenarios were constructed for the SWAT simulation by combining the meteorological data and land-use maps of the corresponding periods:

- S1 (RL1-RC1): land use in 1990 (RL1) and climate during 1991-2000 (RC1).

- S2 (RL1-RC2): land use in 1990 (RL1) and climate during 2000-2010 (RC2).

- S3 (RL2-RC1): land use in 2000 (RL2) and climate during 1991-2000 (RC1).

- S4 (RL2-RC2): land use in 2000 (RL2) and climate during 2000-2010 (RC2).

Thereinto,

S2-S1 represents the effect of recent climate changes on runoff and sediment load, S3-S1 represents the effect of recent land use changes, and S4-S1 represents the combined effect of recent land use and climate changes on runoff and sediment load.

To predict the effects of potential land use and climate changes on runoff and sediment load, two extreme land use change scenarios, DL1 and DL2, were designed according to the results of land use changes in the UYRB over the past 20 years. In the DL1 scenario, the UYRB developed quickly. Bare land was completely utilised and transformed into grassland, while other land use types remained the same. In the DL2 scenario, the Grain for Green Project is efficiently executed, with farmland being transformed into forest. Furthermore, these two land use change scenarios and the predicted meteorological data of GCMs under different emission scenarios were mixed with the measured data to construct 11 design scenarios, as shown in Table 4.

\section{Results}

Changes in Land Use in the UYRB from 1990 to 2014

Temporal Trends and Abrupt Changes in Hydro-Meteorological Factors

Table 3. Comparison between measured and simulated values by the model in the training and validation periods.

\begin{tabular}{|c|c|c|c|c|c|c|c|c|c|c|}
\hline \multirow{2}{*}{ Index } & \multicolumn{2}{|c|}{ Precipitation } & \multicolumn{2}{c|}{ Maximum temperature } & \multicolumn{2}{c|}{ Minimum temperature } \\
\cline { 2 - 11 } \multicolumn{2}{|c|}{} & A1B & A2 & B1 & A1B & A2 & B1 & A1B & A2 & B1 \\
\hline \multirow{3}{*}{ Training } & Correlation coefficient & 0.931 & 0.948 & 0.941 & 0.988 & 0.988 & 0.988 & 0.994 & 0.994 & 0.994 \\
\cline { 2 - 11 } & Nash efficiency coefficient & 0.865 & 0.898 & 0.885 & 0.975 & 0.976 & 0.976 & 0.988 & 0.987 & 0.988 \\
\hline \multirow{2}{*}{ Validation } & Correlation coefficient & 0.92 & 0.936 & 0.937 & 0.987 & 0.986 & 0.987 & 0.992 & 0.992 & 0.992 \\
\cline { 2 - 11 } & Nash efficiency coefficient & 0.842 & 0.827 & 0.876 & 0.94 & 0.931 & 0.948 & 0.97 & 0.963 & 0.971 \\
\hline
\end{tabular}



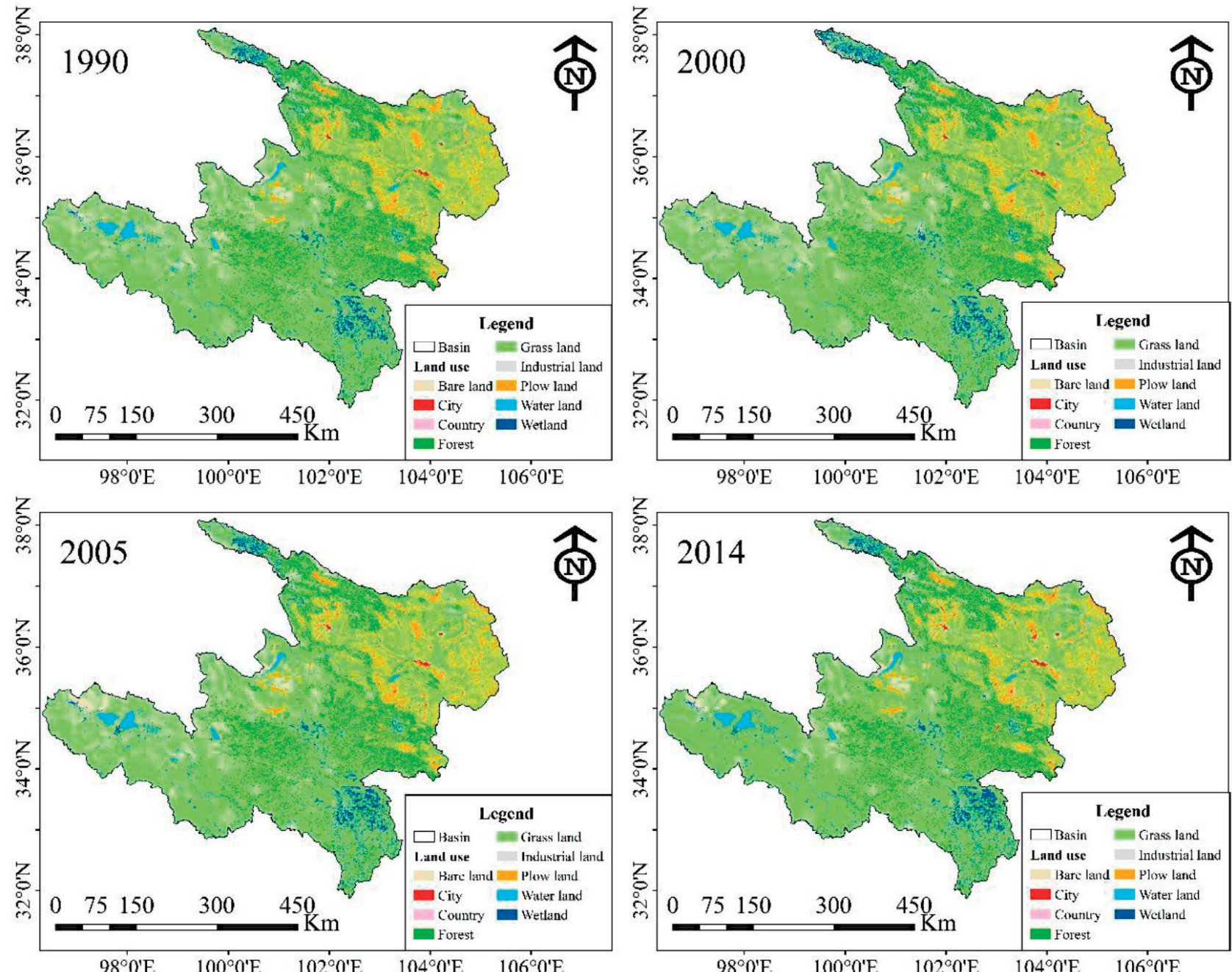

Fig. 3. Land use in the UYRB from 1990 to 2014.

Temporal Trends of Hydro-Meteorological Factors

Abrupt Changes in Hydro-Meteorological Elements

Estimations of Precipitation and Temperature Changes under Different Emission Scenarios

\section{Precipitation Variation Trends}

Temperature Variation Trends

Effects of Recent and Potential Land Use and Climate Changes on Runoff and Sediment Load

\section{Model Calibration and Validation}

\section{Effects of Recent Land Use and Climate Changes on Runoff and Sediment Load}

\section{Effects of Potential Land Use and Climate Changes on Runoff and Sediment Load}

Land use types in the UYRB include grassland, forest, farmland, and bare land, which account for approximately $95 \%$ of the entire basin area (Fig. 3). From 1990 to 2000, forest and grassland frequently transformed in the central area, and the northeastern area grassland transformed into farmland and vice versa (Fig. 4a). From 2000 to 2005, the land use transformation grew more severe. The central area transformed from forest into bare land and grassland, and the northeastern area transformed from grassland to farmland and vice versa. The western area transformed from bare land to grassland and vice versa (Fig. 4b). From 2005 to 2010, the degree of land use transformation lessened. Bare land was massively transformed into grassland in the western area, while grassland and farmland frequently transformed in the northeastern area (Fig. 4c). During the entire survey period (1990-2014), bare land massively transformed into grassland in the western area, while there was no significant land use transformation in the other areas (Fig. 4d).

Land use changes in the UYRB from 1990 to 2000 primarily manifested as mutual transformations among 

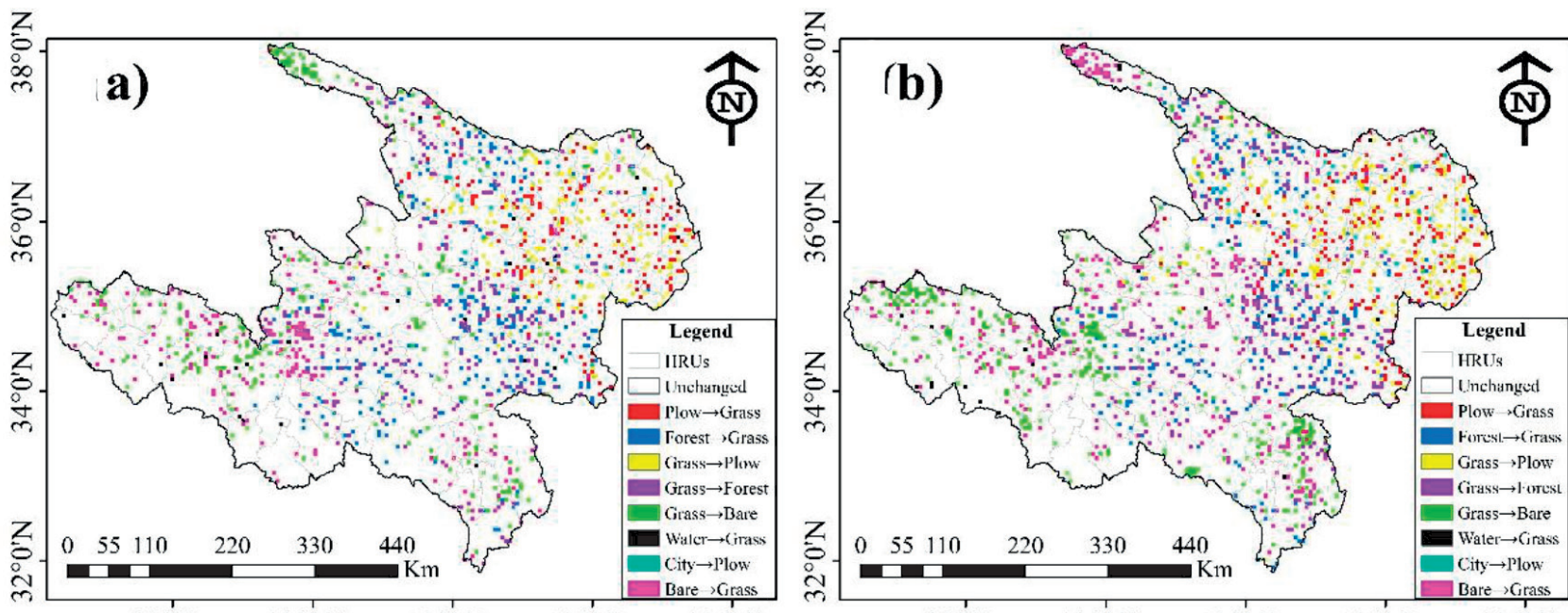

$98^{\circ} 0^{\prime} \mathrm{E} \quad 100^{\circ} 0^{\prime} \mathrm{E} \quad 102^{\circ} 0^{\prime} \mathrm{E} \quad 104^{\circ} 0^{\prime} \mathrm{E} \quad 106^{\circ} 0^{\prime} \mathrm{E}$
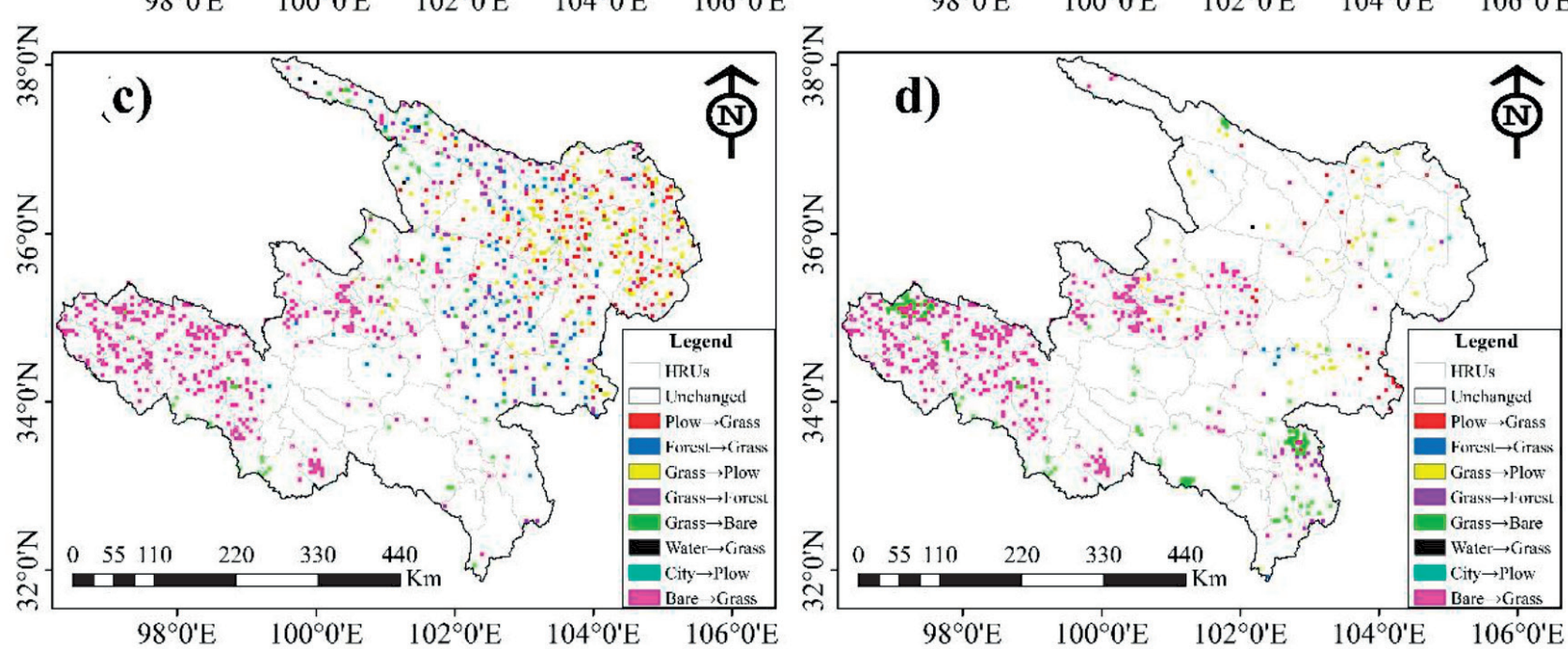

Fig. 4. The spatial distribution of land use transformations for each period in the UYRB: a) from 1990 to 2000, b) from 2000 to 2005 , c) from 2005 to 2014, and d) from 1990 to 2014

grassland, bare land, and wetland (Table 5). The amount of grassland decreased by $0.47 \%$, the amount of bare land was reduced by $1.56 \%$, and the amount of wetland increased by $15.94 \%$. There were no significant changes in other land use types. The above changes were predominately affected by the effective implementation of soil and water conservation measures.

Fig. 5 shows the temporal trends of hydrometeorological factors from 1957 to 2010 in the UYRB. During this period, both the runoff and sediment load

Table 4. Design scenarios of potential land use and climate changes

\begin{tabular}{|c|c|c|c|c|c|}
\hline Scenario & Land-use & Climate & Scenario & Land-use & Climate \\
\hline DS0 & 1990 & $1991 \sim 2010$ & DS6 & DL1 & Climate in A1B \\
\hline DS1 & 1990 & Climate in A1B & DS7 & DL1 & Climate in A2 \\
\hline DS2 & 1990 & Climate in A2 & DS8 & DL1 & Climate in B1 \\
\hline DS3 & 1990 & Climate in B1 & DS9 & DL2 & Climate in A1B \\
\hline DS4 & DL1 & $1991 ~ 2010$ & DS10 & DL2 & Climate in A2 \\
\hline DS5 & DL2 & $1991 ~ 2010$ & DS11 & DL2 & Climate in B1 \\
\hline
\end{tabular}

Note: DS0 is set as the reference scenario. DSi-DS0 $(i=1-, 3)$ represents the impacts of future climate changes on runoff and sediment loads; DSj-DS0 $(j=4,5)$ represents the impacts of potential land use changes on runoff and sediment loads; and DSk-DS0 $(k=6-10)$ represents the combined effects of land use and climate changes. 
Table 5. Land use changes in the UYRB from 1990 to 2000.

\begin{tabular}{|c|c|c|c|c|c|c|}
\hline \multirow{2}{*}{ Land-use type } & \multicolumn{2}{|c|}{1990} & \multicolumn{2}{c|}{2000} & \multicolumn{2}{c|}{ Change } \\
\cline { 2 - 7 } & Area $\left(\mathrm{km}^{2}\right)$ & Percent $(\%)$ & Area $\left(\mathrm{km}^{2}\right)$ & Percent $(\%)$ & Area $\left(\mathrm{km}^{2}\right)$ & Percent $(\%)$ \\
\hline Grassland & 169.39 & 67.22 & 168.59 & 66.89 & -0.79 & -0.47 \\
\hline Forest & 27.72 & 11.00 & 27.72 & 11.00 & 0.01 & 0.04 \\
\hline Farmland & 23.63 & 9.38 & 23.67 & 9.39 & 0.04 & 0.17 \\
\hline Bare land & 19.26 & 7.64 & 18.97 & 7.53 & -0.3 & -1.56 \\
\hline Wetland & 6.46 & 2.56 & 7.49 & 2.97 & 1.03 & 15.94 \\
\hline Water land & 4 & 1.59 & 4.03 & 1.60 & 0.03 & 0.75 \\
\hline Country & 1.21 & 0.48 & 1.23 & 0.49 & 0.02 & 1.65 \\
\hline City & 0.25 & 0.10 & 0.26 & 0.10 & 0.01 & 4.00 \\
\hline Industrial land & 0.09 & 0.04 & 0.09 & 0.04 & 0 & 0.00 \\
\hline
\end{tabular}
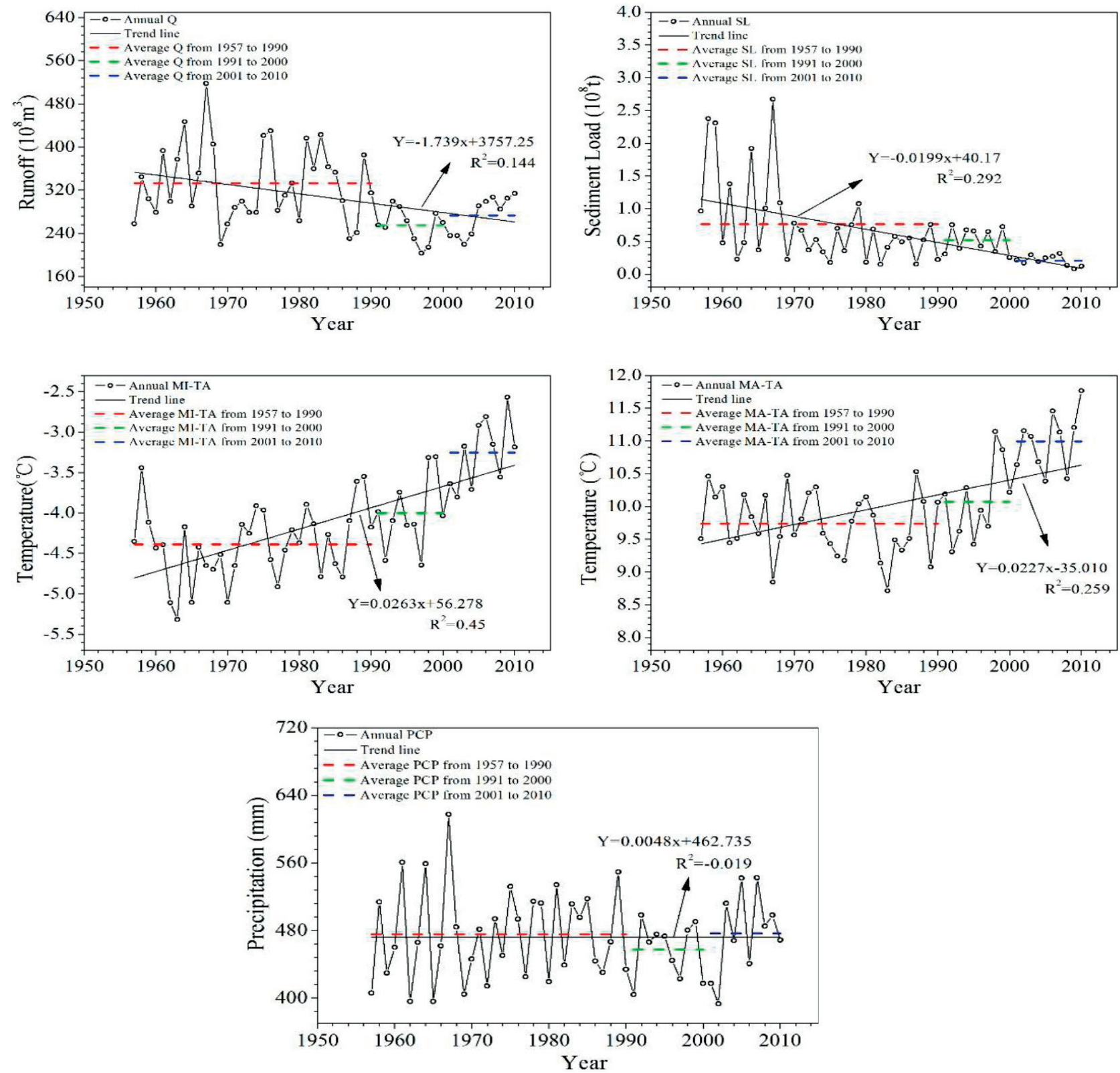

Fig. 5. Temporal trends of hydro-meteorological factors in the UYRB, where $\mathrm{Q}=$ runoff, $\mathrm{SL}=$ sediment load, MI-TA $=$ minimum temperature, $\mathrm{MA}-\mathrm{TA}=$ maximum temperature, and $\mathrm{PCP}=$ precipitation . 

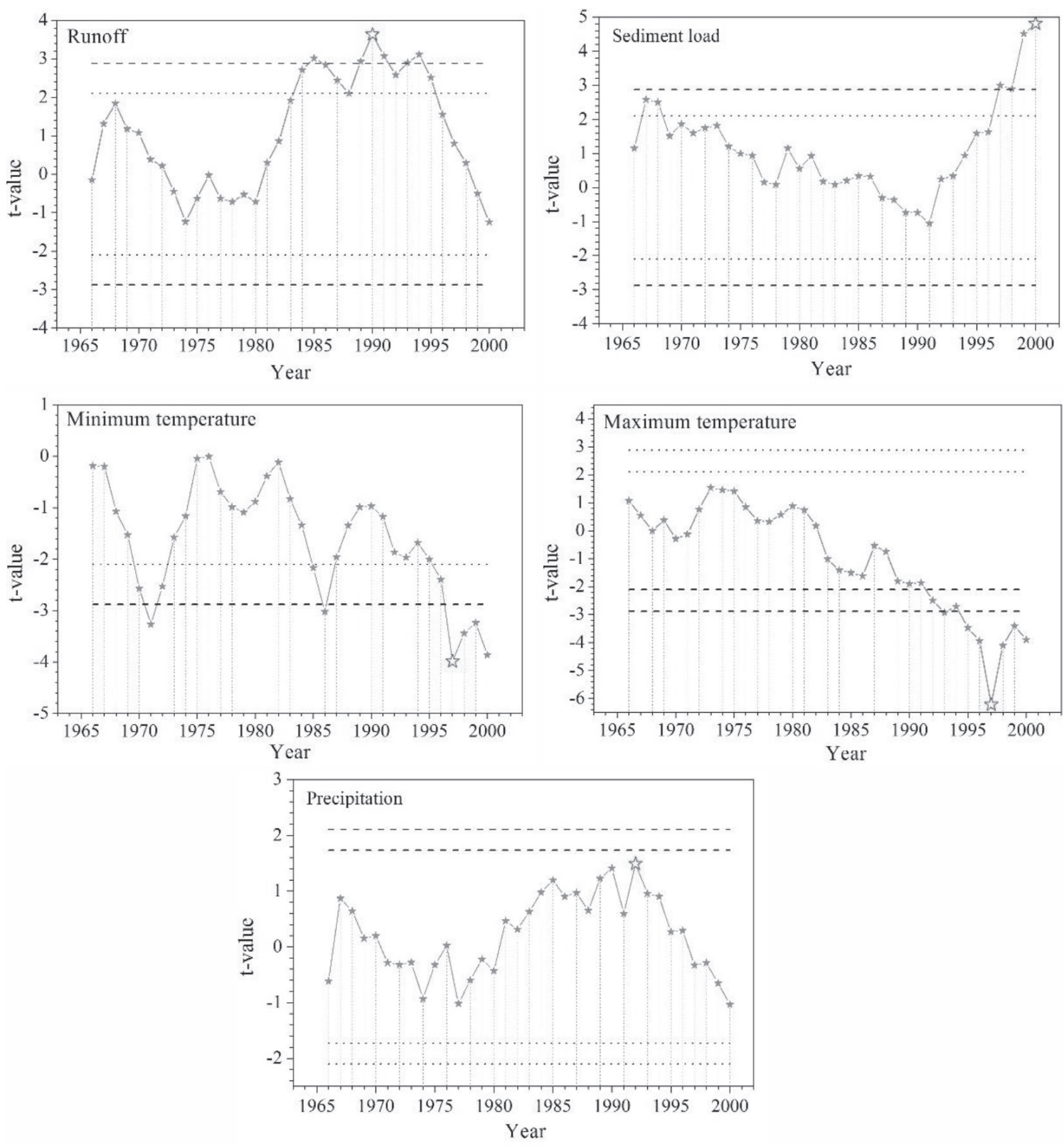

Fig. 6. Abrupt change points of hydro-meteorological factors in the UYRB.

exhibited decreasing trends, with annual change rates of 173.9 million $\mathrm{m}^{3}$ and 2.0 million $\mathrm{t}$, respectively. There were no significant changes in precipitation, which displayed a slight increase, with an annual change rate of $0.005 \mathrm{~mm}$. However, a significant increasing temperature trend during 1957-2010 was detected. The annual rate of increase for the minimum temperature was $0.026^{\circ} \mathrm{C}$ and that of the maximum temperature was $0.023^{\circ} \mathrm{C}$.

The moving-t test was adopted to detect the abrupt change points of hydro-meteorological elements in the UYRB. As shown in Fig. 6, the years 1990 and 2000 were determined to be the change points at the $\alpha=0.05$ significance level for annual runoff and sediment load, respectively. There was no significant abrupt change point in precipitation over the past 50 years. Both the minimum and maximum temperatures exhibited change points in 1997 at the $\alpha=0.05$ significance level. Comprehensively considering the change point detection results, the study period was divided into two sub-periods, one from 1957 to 2000 (before the change point) and the other from 2001 to 2010 (after the change point). In addition, the sub-period before the change point was further divided into recent (1991-2000) and historical (1957-1990).

The average annual runoff, sediment load, precipitation, and minimum and maximum temperature values during the three periods are shown in Fig. 5. The annual runoff after the change point increased by $7.39 \%$ compared with that of the recent period (1991-2000), and it decreased by $17.97 \%$ compared with that of the historical period (1957-1990). The annual sediment load after the change point decreased by $60.6 \%$ and $73.19 \%$ compared with that of the recent and historical 
periods, respectively. However, the annual precipitation after the change point increased by $4.26 \%$ and $0.31 \%$, compared with that of the recent and historical periods, respectively. These results indicate that the change in precipitation was not the dominant factor of the variations in runoff and sediment load in the UYRB.

Compared with the measured period, the precipitation in the UYRB showed an overall increasing trend in the three emission scenarios (Fig. 7). The A2 scenario had the largest precipitation fluctuations, ranging from $-134.2-205.0 \mathrm{~mm}$, with a positive trend in the central and eastern regions and a negative trend in the southwest. Precipitation changes in the A1B scenario ranged from $-59.7-95.1 \mathrm{~mm}$, with a positive trend in the southern region and a negative trend in the other regions. The precipitation change range in the
B1 scenario was $-99.7-144.2 \mathrm{~mm}$, with a positive trend in the southeastern region and a negative trend in the northwest. The positive precipitation trends in rainy areas and negative trends in arid areas further increase the risk of floods and droughts (Fig. 7).

The maximum temperature in most parts of the UYRB showed an increasing trend in the three emission scenarios (Fig. 8). In the A1B scenario, the maximum temperature range was $-0.3-1.2^{\circ} \mathrm{C}$. Apart from a decreasing trend in a few parts of the southwestern and eastern areas, there was an overall increasing trend. In the A2 scenario, the maximum temperature range was $-0.2-1.4^{\circ} \mathrm{C}$. Apart from a decreasing trend in some parts of the western and southern areas, there was an overall increasing trend. In the $\mathrm{B} 1$ scenario, the maximum temperature range was $-0.3-1.8^{\circ} \mathrm{C}$. There was a
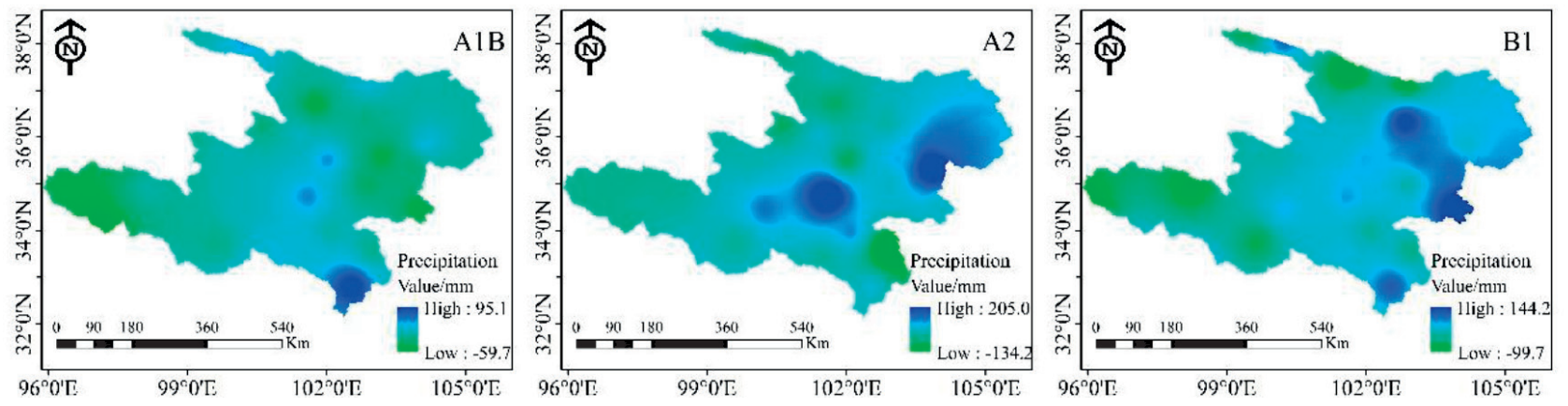

Fig. 7. Spatial distribution of precipitation changes under the A1B, A2, and B1 emission scenarios.
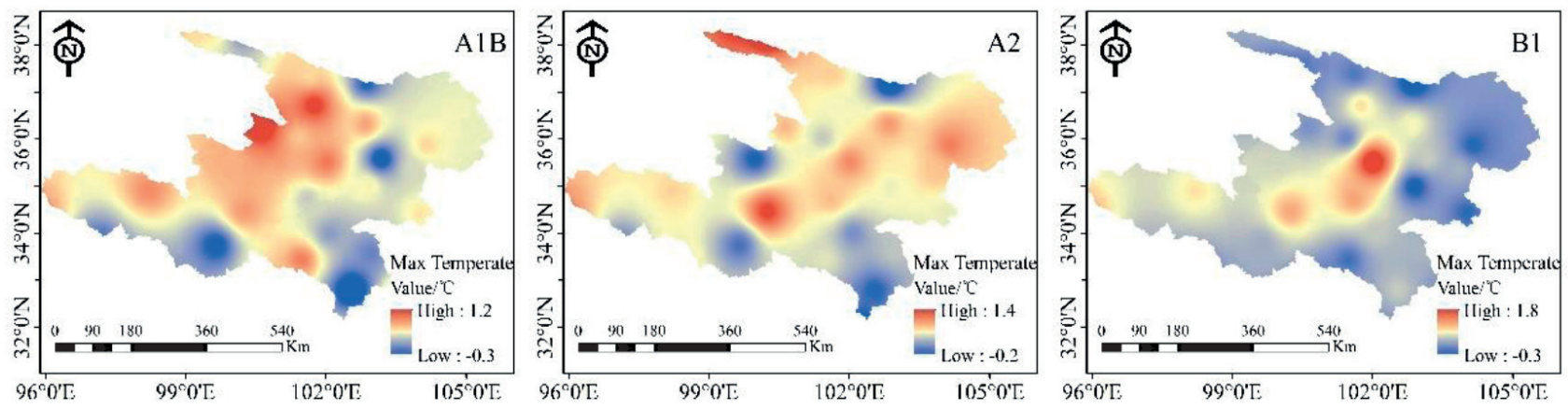

Fig. 8. Spatial distribution of the maximum temperature changes under the A1B, A2, and B1 emission scenarios.
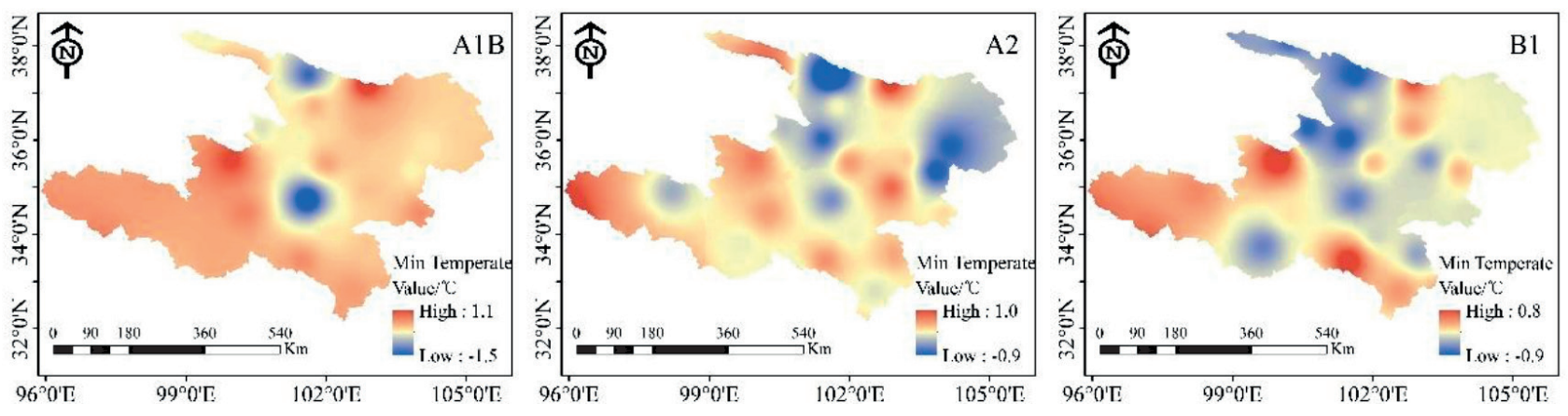

Fig. 9. Spatial distribution of the minimum temperature changes under the A1B, A2, and B1 emission scenarios. 
Table 6. Assessment of the performance of the SWAT model for monthly runoff and sediment load simulations.

\begin{tabular}{|c|c|c|c|c|}
\hline \multirow{2}{*}{ Index } & \multicolumn{2}{|c|}{ Calibration (1994 2000) } & \multicolumn{2}{c|}{ Validation (2001 2010) } \\
\cline { 2 - 5 } & Runoff & Sediment load & Runoff & Sediment load \\
\hline $\mathrm{R}^{2}$ & 0.834 & 0.784 & 0.773 & 0.809 \\
\hline NSE & 0.663 & 0.573 & 0.584 & 0.213 \\
\hline
\end{tabular}

significant increasing trend in the central area and a decreasing trend in the eastern and southern areas.

Similar to the maximum temperature trend, the minimum temperature, in most parts of the UYRB, exhibited an increasing trend in the three emission scenarios (Fig. 9). In the A1B scenario, $v$ the minimum temperature range was $-1.5-1.1^{\circ} \mathrm{C}$. Apart from a decreasing trend in a few parts of the central area, there was an overall increasing. In the A2 scenario, the minimum temperature range was $-0.9-1.0^{\circ} \mathrm{C}$. Apart from a decreasing trend in some parts of the central and eastern areas, there was an overall increasing trend. In the $\mathrm{B} 1$ scenario, the minimum temperature range was $-0.9-0.8^{\circ} \mathrm{C}$. Apart from a significant decreasing trend in the central area, there was an overall increasing trend.

Using the soil type, land use type, and meteorological element data of the URYB as inputs, the SWAT model was constructed using the measured runoff and sediment load data of the Lanzhou station (Fig. 1) as the fitting target. The upper reaches of the Lanzhou station are the main runoff source areas of the Yellow River Basin. As the primary control station, runoff and sediment changes in the Lanzhou station are the primary basis for the hydrological forecasts for the upstream and water and sediment regulation of the downstream.

The SWAT model performance was evaluated using the correlation coefficient $\left(\mathrm{R}^{2}\right)$ and Nash efficiency coefficient (NSE) (Table 6). The $\mathrm{R}^{2}$ in the calibration period exceeded 0.78 , and the NSE was above 0.57 . The simulation accuracy decreased in the validation period, but the $\mathrm{R}^{2}$ was still above 0.77 . The NSE for the sediment load simulation in the validation period was only 0.213 . These results are primarily because dynamic land use changes, which are key factors in the sediment load process, were not considered when
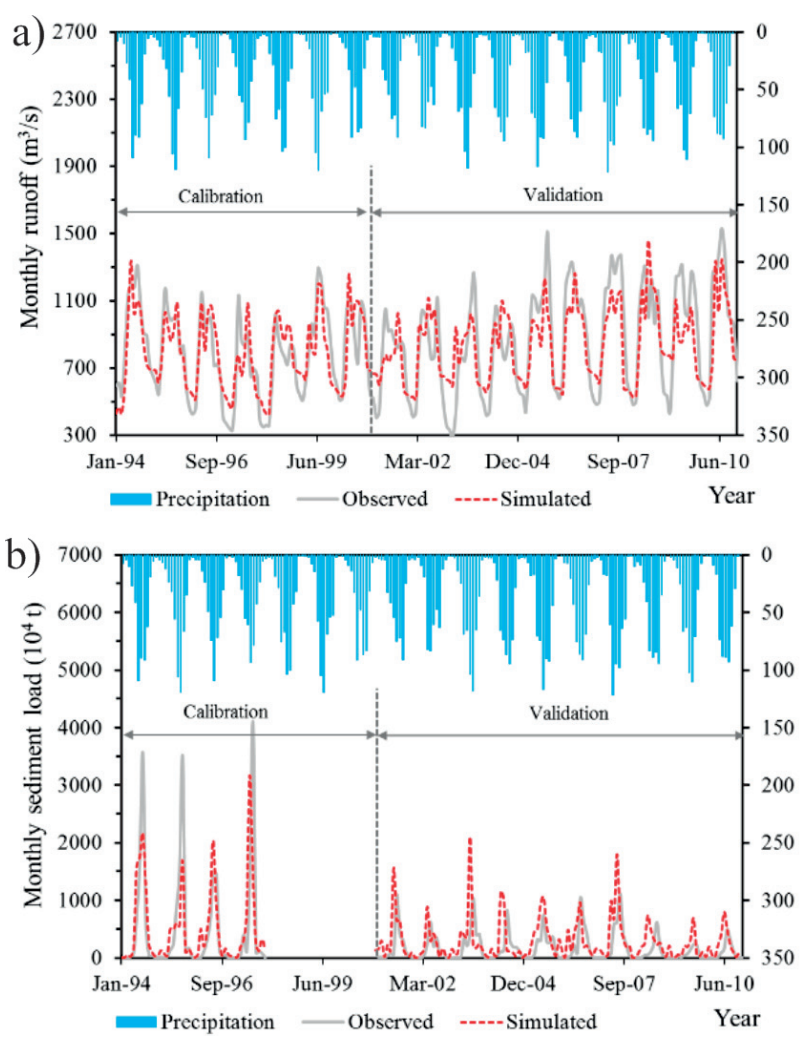

Fig. 10. Monthly runoff a) and sediment load b) simulation results at the Lanzhou station for the calibration period (1994-2000) and validation period (2001-2010).

building the SWAT model. Fig. 10 compared the simulated and measured monthly runoff and sediment load at the Lanzhou station for both the calibration and validation periods. The simulated runoff and sediment results agree with those of the observed change process. However, for both the simulated runoff and sediment load in the calibration period, the peak values are lower than the measured values, and the peak value of the simulated sediment load in the validation period was higher that the measured one.

The land use and meteorological data of scenarios S1-S4 were inputted into the SWAT model to explore the effects of recent land use and climate changes on runoff and sediment load, as shown in Table 7. The simulated runoff in scenario S2 increased by $6.32 \%$ compared with that of scenario S1, which represents the

Table 7. Simulation results of annual average runoff and sediment load under scenarios S1-S4

\begin{tabular}{|c|c|c|c|c|c|c|c|c|}
\hline \multirow{2}{*}{ Scenario } & \multirow{2}{*}{ Land-use } & \multirow{2}{*}{ Climate } & \multicolumn{5}{|c|}{ Runoff } & \multicolumn{3}{|c|}{ Sediment Load } \\
\cline { 5 - 9 } & & $\begin{array}{c}\text { Simulation } \\
\left(\mathrm{m}^{3} / \mathrm{s}\right)\end{array}$ & $\begin{array}{c}\text { Change } \\
\left(\mathrm{m}^{3} / \mathrm{s}\right)\end{array}$ & $\begin{array}{c}\text { Percent } \\
(\%)\end{array}$ & $\begin{array}{c}\text { Simulation } \\
\left(10^{6} \mathrm{t}\right)\end{array}$ & $\begin{array}{c}\text { Change } \\
\left(10^{6} \mathrm{t}\right)\end{array}$ & Percent $(\%)$ \\
\hline S1 & 1990 & $1991 \sim 2000$ & 785.71 & - & - & 42.707 & - & - \\
\hline S2 & 1990 & $2001 \sim 2010$ & 835.35 & 49.64 & 6.32 & 31.76 & -10.947 & -25.63 \\
\hline S3 & 2000 & $1991 \sim 2000$ & 761.24 & -24.47 & -3.11 & 33.37 & -9.337 & -21.86 \\
\hline S4 & 2000 & $2001 \sim 2010$ & 829.26 & 43.55 & 5.54 & 30.22 & -12.487 & -29.24 \\
\hline
\end{tabular}


impact of climate changes. The difference in simulated runoff between scenarios S3 and $\mathrm{S} 1$, which indicates the impact of land use change, decreased by $3.11 \%$. Compared with scenario S1, the combined effects of land use and climate changes under scenario S4 increased the runoff by $5.54 \%$, which is similar to that in scenario S1. The above changes indicate that recent climate changes had a greater impact on runoff than recent land use changes. The simulated sediment loads were less under the other three scenarios compared to those in scenario S1. The simulated sediment load in scenario S2 decreased by $25.63 \%$, that in scenario S3 decreased by $21.86 \%$, and that in scenario S4 decreased by $29.24 \%$. These results indicate that both land use and climate changes greatly impacted sediment load.

\section{Effects of Potential Climate Change on Runoff and Sediment Load}

Fig. 11 shows the simulation results of the average annual runoff and sediment load in different future climate change scenarios (DS0-DS3). The prediction period, 2021-2100, was divided into three stages: the 2030s (2021-2040), 2060s (2041-2070), and 2090s (2071-2100). There was a positive correlation between runoff and sediment load changes in the different scenarios, and the variation in sediment load was more dramatic than that in runoff. The simulated runoff and sediment load in the DS1 and DS3 climate change scenarios decreased compared with that in the DS0 reference scenario. In the DS1 scenario, the decrease in runoff and sediment load was the sharpest. The simulated runoff in the 2030s of the DS1 scenario decreased by $6.77 \%$, compared with that in DS0, and the sediment load was reduced by $18.75 \%$. There was an overall increasing trend for runoff and sediment load in the DS2 scenario. The simulated runoff in in the 2090s increased by $7.54 \%$ compared with that in the reference scenario (DS0), and the sediment load increased by $13.56 \%$. The above phenomenon demonstrates that future climate changes can significantly impact runoff and sediment load in the UYRB.

\section{Effects of Potential Land Use Changes on Runoff and Sediment Load}

The simulated average annual runoff and sediment load in the different land use change scenarios, DS4 and DS5, were compared with those in the reference scenario (DS0) to evaluate the impacts of potential land use changes on runoff and sediment load, as shown in Fig. 12. In the two designed land use scenarios, the simulation results for the average annual runoff and sediment load values were less than those in the reference scenario. The simulated runoff in the DS4 scenario was reduced by $8.90 \%$, and the simulated
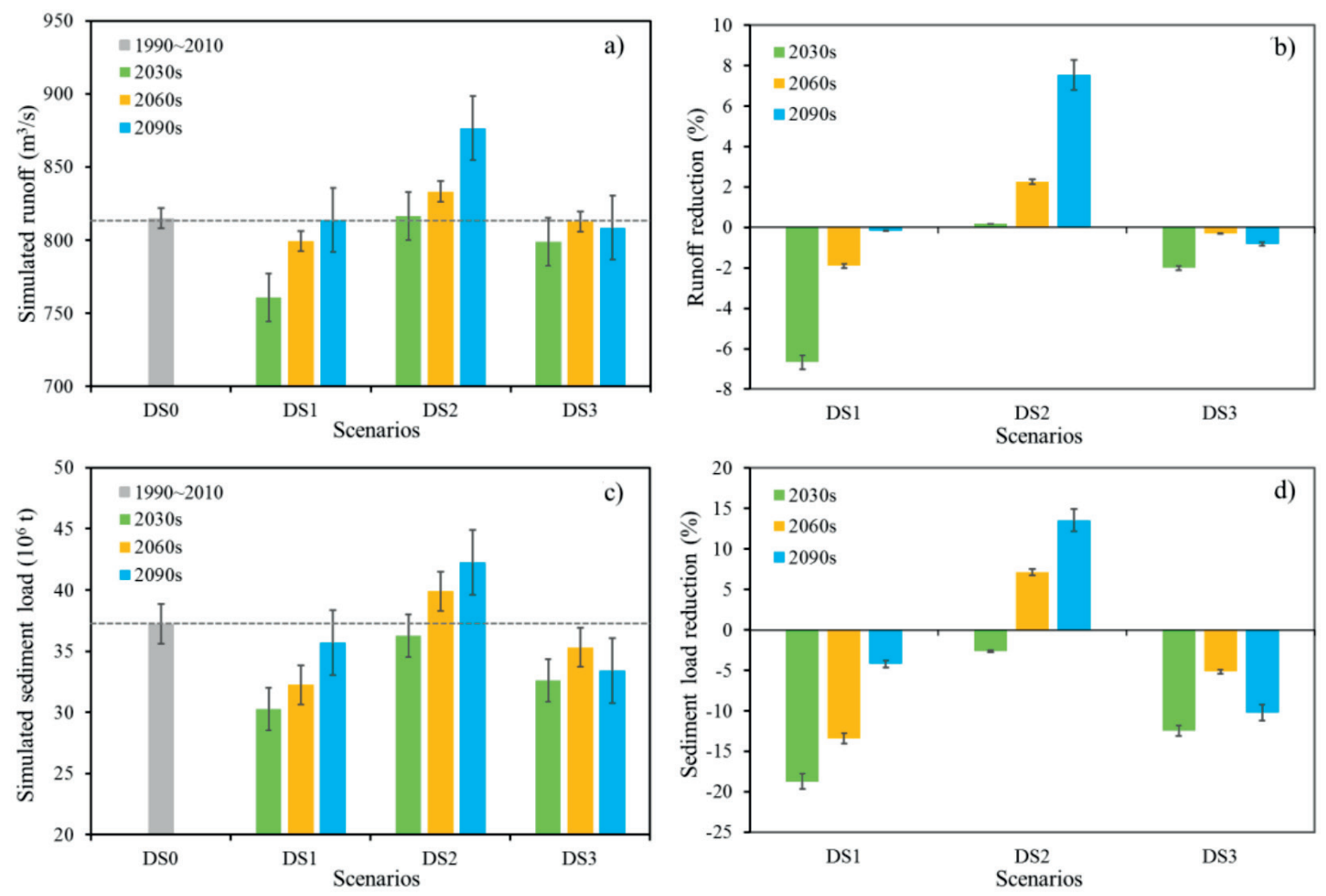

Fig. 11. Simulation results of the average annual runoff and sediment load under different climate change scenarios. a) and c) The simulated average annual runoff and sediment load in the reference and future climate change scenarios. b) and d) The reduction in runoff and sediment load in climate change scenarios compared with that in the reference scenario. 

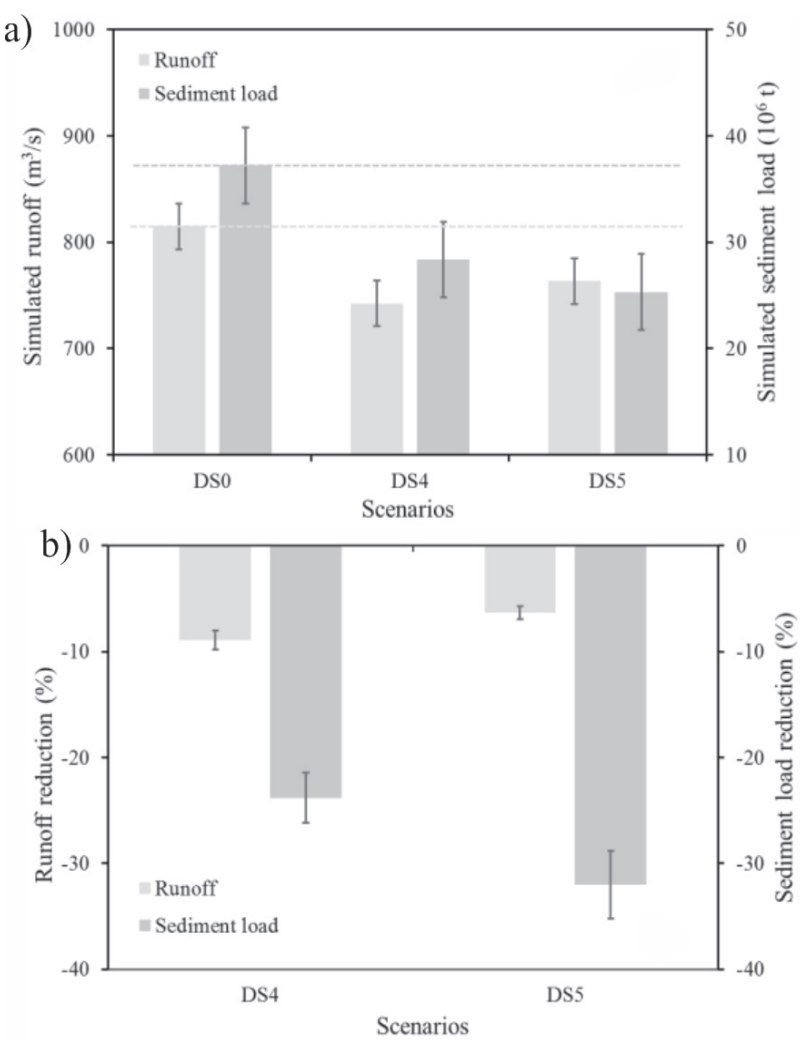

Fig. 12. Simulation results of the average annual runoff and sediment load under different land use change scenarios a), and the reduction in runoff and sediment load under different land use change scenarios $b$ ).

sediment load was reduced by $23.82 \%$. Land use changes in the DS5 scenario decreased the runoff and sediment load by $6.32 \%$ and $32.03 \%$, respectively, compared to those in the reference scenario (DS0). This result indicates that potential land use changes had more significant effects on sediment load than runoff in the UYRB.

\section{Combined Effects of Land Use and Climate Changes on Runoff and Sediment Load}

The simulated average annual runoff and sediment load in the DS6-DS11 scenarios were compared with those in the reference scenario (DS0) to explore the combined effects of potential land use and climate changes on runoff and sediment load, as shown in Fig. 13. In each designed scenario, under the combined effects of land use and climate changes, the average annual runoff and sediment load were less than that in the reference scenario. The sharpest reduction occurred in the DS11 scenario, where the simulated runoff and sediment load decreased by $15.01 \%$ and $53.56 \%$, respectively, compared with that of the DS0 scenario. In the DS7 scenario, the reduction was the smallest. The simulated runoff decreased by $4.50 \%$, and the simulated sediment load decreased by $13.64 \%$ compared with that in the reference scenario.
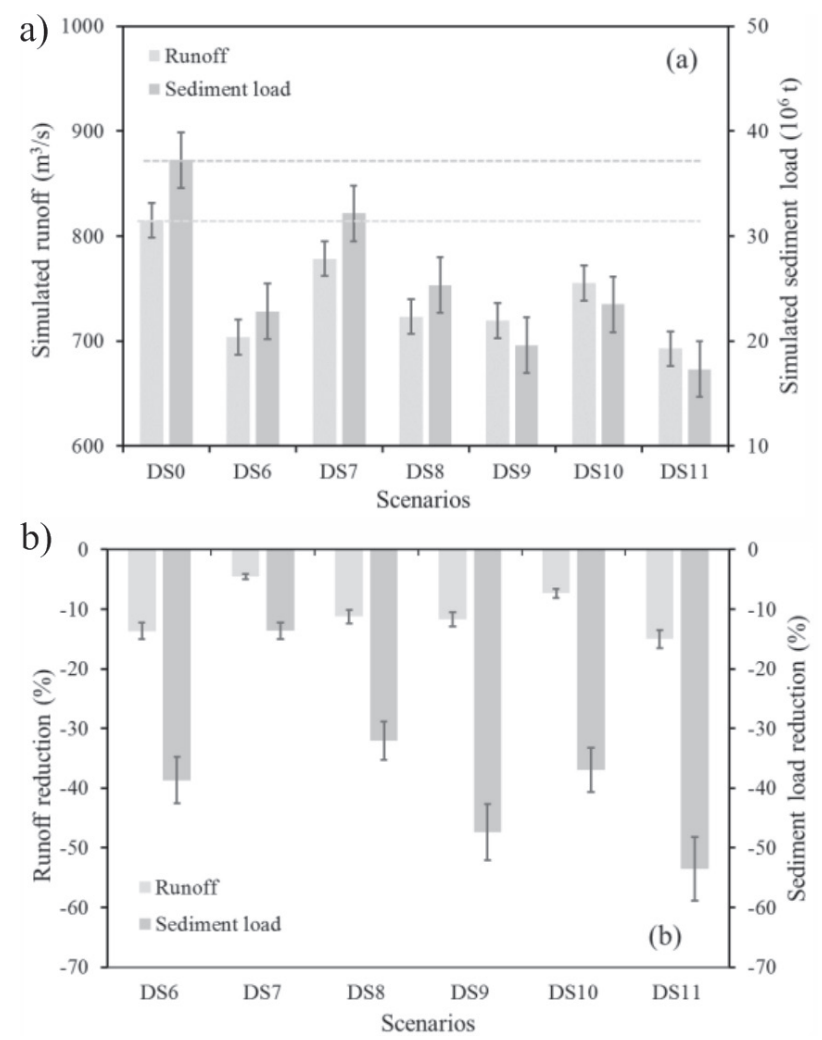

Fig. 13. Simulation results of the average annual runoff and sediment load under combined land use and climate changes scenarios a) and the reduction in runoff and sediment load under combined land use and climate changes scenarios b).

\section{Discussion}

Human activities and climate changes have altered land use features and the local climate in the UYRB, which affect runoff and sediment load [38-40]. The results of this study show that there were significant decreasing trends for runoff and sediment load in the UYRB from 1957 to 2010 (Fig. 5), which was similar to those found in other research $[38,41]$. This phenomenon predominately resulted from both climate and land use changes. On the one hand, a rise in temperature increased the evapotranspiration in the UYRB, melting massive amounts of permafrost in the source region of the Yellow River [42], and the capacity of soil to regulate and store precipitation was strengthened [43]. On the other hand, the "Grain for Green Project" was implemented in the UYRB in 2000 and "Three Rivers Source Region Reserve" was implemented in 2005 [41]. Afterwards, the amount of grassland, forest, and wetland areas increased, which can help to conserve water and soil. The combined effects of these factors reduced the runoff and weakened the sediment carrying capacity of the Yellow River. During the period 2001-2010 (after the change point), the runoff in the UYRB increased by $7.39 \%$, which can be attributed to the increase in precipitation (4.26\%) (Fig. 5). The decrease in sediment load by $60.6 \%$ can be primarily be attributed to land use change (Figs 4 and 5). 
According to the SWAT model simulation results, climate changes from 2001 to 2010 increased the runoff in the UYRB by $6.32 \%$ compared with that in 19912000 , which was similar to the measured increase (7.39\%) (Table 7 and Fig. 5). Land use changes reduced the runoff by $3.11 \%$. The runoff increased by $5.54 \%$ under the combined effects of land use and climate changes, which was similar to that of under the effects of climate changes alone. These results indicate that the recent climate changes had a more significant effect on runoff in the UYRB than the recent land use changes $[29,44]$. From 2001 to 2010, climate changes reduced the sediment load by $25.63 \%$ compared with that in 1991-2000. Land use changes reduced the sediment load by $21.86 \%$. The combined effects of the land use and climate changes reduced the sediment load by $29.24 \%$, which was significantly different from the measured value $(60.6 \%)$ (Table 7 and Fig. 5). This result was obtained primarily because dynamic land use changes after 2000 were not considered in the model. This was the peak period for the construction of soil and water conservation measures in the UYRB with dramatic changes in land use that had a significant impact on sediment load [45].

Compared with the reference scenario (DS0), the runoff and sediment load decreased significantly in the DS1 and DS3 climate change scenarios with slight increasing trends in precipitation and significant increasing trends in temperature. These results demonstrate the sensitivity of runoff and sediment load in the UYRB to temperature changes $[46,47]$. However, the simulated runoff and sediment load in the DS2 scenario showed an overall increasing trend, which was mainly due to the significant increase in precipitation (Figs 7 and 11). These prediction results were inconsistent with those in [17], which was due to differences in the GCM patterns and study area. In the DS4 and DS5 land use change scenarios, the transformation from bare land into grassland or from farmland into forest in the UYRB significantly decreased the runoff and sediment. This demonstrated that the soil and water conservation capacities of forest and grassland were superior to those of bare land and farmland [48]. There were similar trends in runoff and sediment load under the combined effects of land use and climate changes as those in the scenarios with only land use changes (Figs 12 and 13). This result indicates that the effects of potential land use changes on runoff and sediment load in the UYRB are substantial.

\section{Conclusions}

The climate in the UYRB from 1957 to 2010 grew warmer and wetter, and the runoff and sediment load were significantly reduced. According to the prediction results from different emission scenarios, the warm and wet climate characteristics of the UYRB will continue to develop in the next 80 years. A large area of bare land transformed into grassland in the western area of the UYRB due to the efficient implementation of ecological protection projects over the past 20 years (1990-2010).

According to the SWAT model simulation results, the climate changes in the UYRB had a more significant impact on runoff than land use changes over the past 20 years, increasing the runoff. However, the reduction in sediment load was affected by both land use and climate changes. The simulated UYRB runoff and sediment load exhibited a decreasing trend for the next 80 years in the DS1 and DS3 scenarios, with a slight increase in precipitation and significant increase in temperature compared with those in the reference scenario (DS0). The runoff and sediment load increased in the DS2 scenario with a significant increase in both precipitation and temperature. Compared with climate changes, potential land use changes can more significantly impact runoff and sediment load in the next 80 years. The transformation from bare land to grassland or farmland to forest land can significantly reduce both runoff and sediment transport.

\section{Acknowledgements}

The researchers would like to extend their thanks to the National Key Research and Development Project (No. 2017YFA0605004; No.2016YFA0601503), the National Science Fund for Distinguished Young Scholars (No. 51725905).

\section{Conflict of Interest}

The authors declare that there are no conflicts of interest regarding the publication of this paper.

\section{References}

1. CARLTON J.S., MASE A.S., KNUTSON C.L., LEMOS M.C., HAIGH T., TODEY D.P., PROKOPY L.S. The effects of extreme drought on climate change beliefs, risk perceptions, and adaptation attitudes. Climatic Change. 135, 211, 2016.

2. KIM J., CHOI J., CHOI C., PARK S. Impacts of changes in climate and land use/land cover under IPCC RCP scenarios on streamflow in the Hoeya River Basin, Korea. Sci Total Environ. 452-453, 181, 2013.

3. LI H. Effects of Human Activities in the Wei River Basin on the Lower Yellow River, China. Pol J Environ Stud. 26, 2555, 2017.

4. CHU M.L., KNOUFT J.H., GHULAM A., GUZMAN J.A., PAN Z. Impacts of urbanization on river flow frequency: A controlled experimental modeling-based evaluation approach. J Hydrol. 495, 1, 2013.

5. EVARISTO J., JASECHKO S., MCDONNELL J.J. Global separation of plant transpiration from groundwater and streamflow. Nature. 525, 91, 2015.

6. PLUMB B.D., ANNABLE W.K., THOMPSON P.J., HASSAN M.A. The Impact of Urbanization on Temporal 
Changes in Sediment Transport in a Gravel Bed Channel in Southern Ontario, Canada. Water Resour Res. 53, 2017.

7. HE Y., WANG F., TIAN P., MU X.M., GAO P., ZHAO G.J., WU Y.P. Impact Assessment of Human Activities on Runoff and Sediment of Beiluo River in the Yellow River Based on Paired Years of Similar Climate. Pol J Environ Stud. 25, 121, 2016.

8. CHIEN H., YEH J.F., KNOUFT J.H. Modeling the potential impacts of climate change on streamflow in agricultural watersheds of the Midwestern United States. J Hydrol. 491, 73, 2013.

9. MUÑOZ-SALINAS E., CASTILlO M. Streamflow and sediment load assessment from 1950 to 2006 in the Usumacinta and Grijalva Rivers (Southern Mexico) and the influence of ENSO. Catena. 127, 270, 2015.

10. WEI Y., JIAO J., ZHAO G., ZHAO H., HE Z., MU $X$. Spatial-temporal variation and periodic change in streamflow and suspended sediment discharge along the mainstream of the Yellow River during 1950-2013. Catena. 140, 105, 2016.

11. ZHANG J., ZHANG X., LI R., CHEN L., LIN P. Did streamflow or suspended sediment concentration changes reduce sediment load in the middle reaches of the Yellow River? J Hydrol. 546, 357, 2017.

12. ZHAO G., TIAN P., MU X., JIAO J., WANG F., GAO P. Quantifying the impact of climate variability and human activities on streamflow in the middle reaches of the Yellow River basin, China. J Hydrol. 519, 387, 2014.

13. ZHENG H., ZHANG L., LIU C., SHAO Q., FUKUSHIMA Y. Changes in stream flow regime in headwater catchments of the Yellow River basin since the 1950s. Hydrol Process. 21, 886, 2010.

14. LIANG S., GE S., WAN L., ZHANG J. Can climate change cause the Yellow River to dry up? Water Resour Res. 2010.

15. WANG H., BI N., SAITO Y., WANG Y., SUN X., ZHANG J. YANG Z. Recent changes in sediment delivery by the Huanghe (Yellow River) to the sea: Causes and environmental implications in its estuary. J Hydrol. 391, 302, 2010.

16. PENG J., CHEN S., DONG P. Temporal variation of sediment load in the Yellow River basin, China, and its impacts on the lower reaches and the river delta. Catena. 83, 147, 2010.

17. ZHANG Y., SU F., HAO Z., XU C., YU Z., WANG L., TONG K. Impact of projected climate change on the hydrology in the headwaters of the Yellow River basin. Hydrol Process. 29, 4379, 2015.

18. KONG D., MIAO C., WU J., DUAN Q. Impact assessment of climate change and human activities on net runoff in the Yellow River Basin from 1951 to 2012. Ecol Eng. 91, 566, 2016.

19. KONG D., MIAO C., WU J., DUAN Q. Impact assessment of climate change and human activities on net runoff in the Yellow River Basin from 1951 to 2012. Ecol Eng. 91, 566, 2016.

20. LIU L., LIU Z., REN X., FISCHER T., XU Y. Hydrological impacts of climate change in the Yellow River Basin for the 21st century using hydrological model and statistical downscaling model. Quatern Int. 244, 211, 2011.

21. WANG F., HESSEL R., MU X., MAROULIS J., ZHAO G., GEISSEN V., RITSEMA C. Distinguishing the impacts of human activities and climate variability on runoff and sediment load change based on paired periods with similar weather conditions: A case in the Yan River, China. J Hydrol. 527, 884, 2015.
22. KHOI D.N., SUETSUGI T. The responses of hydrological processes and sediment yield to land-use and climate change in the Be River Catchment, Vietnam. Hydrol Process. 28, 640, 2014.

23. MCCORMICK B.C., ESHLEMAN K.N., GRIFFITH J.L., TOWNSEND P.A. Detection of flooding responses at the river basin scale enhanced by land use change. Water Resour Res. 45, 3900, 2009.

24. NOTEBAERT B., VERSTRAETEN G., WARD P., RENSSEN H., Van ROMPAEY A. Modeling the sensitivity of sediment and water runoff dynamics to Holocene climate and land use changes at the catchment scale. Geomorphology. 126, 18, 2011.

25. ZHAO F., XU Z., LU Z. Changes in streamflow regime following vegetation changes from paired catchments. Hydrol Process. 26, 1561, 2012.

26. ZUO D., XU Z., YAO W., JIN S., XIAO P., RAN D. Assessing the effects of changes in land use and climate on runoff and sediment yields from a watershed in the Loess Plateau of China. Sci Total Environ. 544, 238, 2016.

27. WORKU T., KHARE D., TRIPATHI S.K. Modeling runoff-sediment response to land use/land cover changes using integrated GIS and SWAT model in the Beressa watershed. Environ Earth Sci. 76, 550, 2017.

28. HOVENGA P.A., WANG D., MEDEIROS S.C., HAGEN S.C., ALIZAD K. The response of runoff and sediment loading in the Apalachicola River, Florida to climate and land use land cover change. Earth's Future. 4, 124, 2016.

29. WANG S., ZHANG Z., R. MCVICAR T., GUO J., TANG Y., YAO A. Isolating the impacts of climate change and land use change on decadal streamflow variation: Assessing three complementary approaches. J Hydrol. 507, 63, 2013.

30. JAA A., FLANAGAN D.C., SRIVASTAVA A., WENDLAND E.C. Land use and climate change impacts on runoff and soil erosion at the hillslope scale in the Brazilian Cerrado. Sci Total Environ. 622-623, 140, 2017.

31. ZHANG Y., REN B., HURSTHOUSE A.S., DENG R., HOU B. An Improved SWAT for Predicting Manganese Pollution Load at the Soil-Water Interface in a Manganese Mine Area. Pol J Environ Stud. 27, 2357, 2018.

32. NILAWAR A.P., WAIKAR M.L. Impacts of climate change on streamflow and sediment concentration under RCP 4.5 and 8.5: A case study in Purna river basin, India. Sci Total Environ. 650, 2685, 2019.

33. DIDOVETS I., KRYSANOVA V., BÜRGER G., SNIZHKO S., BALABUKH V., BRONSTERT A. Climate change impact on regional floods in the Carpathian region. Journal of Hydrology: Regional Studies. 22, 100590, 2019.

34. WAGENA M.B., SOMMERLOT A., ABIY A.Z., COLLICK A.S., LANGAN S., FUKA D.R., EASTON Z.M. Climate change in the Blue Nile Basin Ethiopia: implications for water resources and sediment transport. Climatic Change. 139, 1, 2016.

35. LIANG L., LI L., LIU C., CUO L. Climate change in the Tibetan Plateau Three Rivers Source Region: 1960-2009. Int J Climatol. 33, 2013.

36. XU Y., XU C., GAO X., LUO Y. Projected changes in temperature and precipitation extremes over the Yangtze River Basin of China in the $21^{\text {st }}$ century. Quatern Int. 208, 52, 2009.

37. HIMANSHU S.K., PANDEY A., SHRESTHA P. Application of SWAT in an Indian river basin for modeling runoff, sediment and water balance. Environ Earth Sci. 76, 3, 2017. 
38. YAO, WENYI. XU Impact of human activity and climate change on suspended sediment load:; the upper Yellow River, China. Environ Earth Sci. 70, 1389, 2013.

39. WANG T., YANG H., YANG D., QIN Y., WANG Y. Quantifying the streamflow response to frozen ground degradation in the source region of the Yellow River within the Budyko framework. J Hydrol. 558, 301, 2018.

40. WANG G., BAI W., LI N., HU H. Climate changes and its impact on tundra ecosystem in Qinghai-Tibet Plateau, China. Climatic Change. 106, 463, 2011.

41. LAN C., ZHANG Y., GAO Y., HAO Z., CAIRANG L. The impacts of climate change and land cover/use transition on the hydrology in the upper Yellow River Basin, China. J Hydrol. 502, 37, 2013.

42. XU S., YU Z., YANG C., JI X., ZHANG K. Trends in evapotranspiration and their responses to climate change and vegetation greening over the upper reaches of the Yellow River Basin. Agr Forest Meteorol. 263, 118, 2018.

43. MENG F., SU F., YANG D., TONG K. HAO Z. Impacts of recent climate change on the hydrology in the source region of the Yellow River basin. Journal of Hydrology: Regional Studies. 6, 66, 2016.
44. YUTONG Z., YUEFEI H., SHA Z., KEYI W. GUANGQIAN W. Effect partition of climate and catchment changes on runoff variation at the headwater region of the Yellow River based on the Budyko complementary relationship. Sci Total Environ. 2018.

45. SHI H., HU C., WANG Y., LIU C., LI H. Analyses of trends and causes for variations in runoff and sediment load of the Yellow River. Int J Sediment Res. 2016.

46. QIN Y., YANG D., GAO B., WANG T., CHEN J., CHEN Y., WANG Y., ZHENG G. Impacts of climate warming on the frozen ground and eco-hydrology in the Yellow River source region, China. Sci Total Environ. 605-606, 830, 2017.

47. XIAOLING W., XIN Z., XIAOHUA X., KE Z., HUIJUN J., XI C., CHUANHAI W., QUANQIN S., WENJUAN $\mathrm{H}$. Changing runoff generation in the source area of the Yellow River: Mechanisms, seasonal patterns and trends. Cold Reg Sci Technol. S165232X, 2018.

48. YANG W., LONG D., BAI P. Impacts of future land cover and climate changes on runoff in the mostly afforested river basin in North China. J Hydrol. 570, 201, 2019. 